\title{
On the Endoscopic Methods Used with Questionable Indications
}

Keywords: Endoscopy; Bronchosc opy; Bronchial asthma; Bronchitis; Pneumonia; Tuberculosis

\section{Introduction}

This letter is a continuation of the series of reports on invasive procedures applied in the former Soviet Union (SU) with questionable clinical indications, also for research [1-4]. The problem is still with us: partial isolation from the international scientific community resulting in persistence of suboptimal practices. In this letter, special attention is given to the bronchoscopy (Bs) in bronchial asthma, used in spite of the widespread opinion that it brings not much benefit [5]. In the international literature, no particular role of Bs in the diagnosis and treatment of asthma has been specified, asthmatics being regarded at enhanced risk for complications from this procedure [5]. Among indications for Bs in asthma are persistent wheeze unresponsive to bronchodilators and other adequate therapy [6,7]. While there are other diagnostic tests, the most common indication for Bs in asthma is a search for alternative causes of the symptoms [6]. Lavage of bronchi can be indicated in severe asthma in certain circumstances $[8,9]$. More precise formulations are avoided here because this letter is not an instructive publication. The newest Russian-language textbooks are largely based on the international literature. However, earlier textbooks and manuals contained recommendations partly at variance with internationally accepted approaches. In asthmatics, the purpose of Bs was declared to be the search for signs of dependence of the pathological process on the infection and characterization of inflammatory lesions $[10,11]$. Abundant secretion or mucopurulent sputum in a child was presented as an indication for Bs "for evaluation of the endobronchial inflammation" [12]. It was stated in the instructive monograph [11] that in children Bs is recommended "almost in all subacute and chronic respiratory diseases". Asthma, tuberculosis $(\mathrm{Tb})$, bronchitis, and protracted pulmonary or bronchial conditions in general, were posited as indications for Bs [13-18].

Extension of indications for Bs compared to the more conservative earlier manuals $[19,20]$ is associated with the names of Lev Ioffe and Fedor Uglov [21-26]. Ioffe wrote in an instructive edition that "Bs must be performed in all pulmonary diseases" [21]. In 1976, Uglov reported on 2477 therapeutic and 5000 diagnostic Bs performed in his institution in patents aged 1.5-78 years predominantly with inflammatory diseases such as bronchitis, pneumonia and asthma, aimed at the "assessment of inflammatory changes in the bronchial tree" [25]. The conclusion was that Bs is important for the detailed diagnosis of practically all pulmonary diseases and can be recommended also at an early stage [25]. "After a prolonged course of therapeutic Bs" Uglov applied resections of pulmonary segments or lobes deemed irreversibly changed (bronchitis deformans, bronchiectasis etc.) as a treatment method of asthma [25]; more details are in [1]. Many thousands Bs performed with or without concomitant bronchography in children and adults with non-specific

\section{Journal of} Surgery

\section{Sergei V. Jargin*}

Department of Pathology, People's Friendship University of Russia, Russian Federation, University of Russia, Russia

\section{*Address for Correspondence}

Sergei V. Jargin, Department of Pathology, People's Friendship University of Russia, Russian Federation, University of Russia, Clementovski per 6-82, 115184 Moscow, Russia, Tel: +7 495 9516788; E-mail: sjargin@mail.ru

\section{Submission: 21 July, 2016}

Accepted: 26 July, 2016

Published: 01 August, 2016

Copyright: (๑) 2016 Jargin SV. This is an open access article distributed under the Creative Commons Attribution License, which permits unrestricted use, distribution, and reproduction in any medium, provided the original work is properly cited.

Reviewed \& Approved by: Dr. Josef Kainz, Department of General ENT, Medical University of Graz, Austria

respiratory diseases were reported also from peripheral institutions and outpatient facilities [26]. In the same edition, difficulties with the local anesthesia were pointed out, which necessitated general anesthesia in $20-25 \%$ of the patients [26]. Apparently, the widespread implementation of endoscopy occurred according to a directive. Interference of authorities with science has been a well-known phenomenon in the former SU [27]. With regard to the medical practice, the so-called administrative factor [28] has played a role: the support of certain methods by the health care authorities, who sometimes favored less individualized approaches applicable to large categories of patients. In consequence of the authoritative management style, some methods, outdated or generally unsupported by the international literature, were applied for long periods of time; overviewed in [1].

\section{Overuse of Bronchoscopy}

Bs was applied and recommended in children and adults with bronchial asthma both during remissions and exacerbations, in mild and severe cases [29-37], as well as in the "pre-asthma" i.e. bronchitis with "elements" of bronchospasm and allergy [32,35]. Bs was discussed as a method of "early diagnosis" of all forms of bronchial asthma; it was used repeatedly "for a dynamic observation" [33]. Some experts applied up to 15 bronchoscopies (1-2 weekly) in pediatric asthma [38].

Efficiency of therapeutic Bs in moderate bronchitis was pointed out by Uglov, who applied 5-6 bronchoscopies per treatment course [24]. In particular, the "atrophic type" of chronic bronchitis was regarded as an indication for Bs [15]. Laser therapy was applied in children and adults via bronchoscope in asthma, bronchitis and chronic pneumonia [15,39-43], also in the presence of pronounced atrophy of bronchial mucosa [41], in atrophic bronchitis [44,45] or "primary atrophic bronchopathy" including that supposedly caused by ionizing radiation [46], while histological specimens were thick and difficult to evaluate (Figure 1). Note that, similarly to other forms of electromagnetic radiation, laser at lower power densities causes warming and at higher densities - damage of tissues. From the viewpoint of general pathology, atrophy may advance due to an 


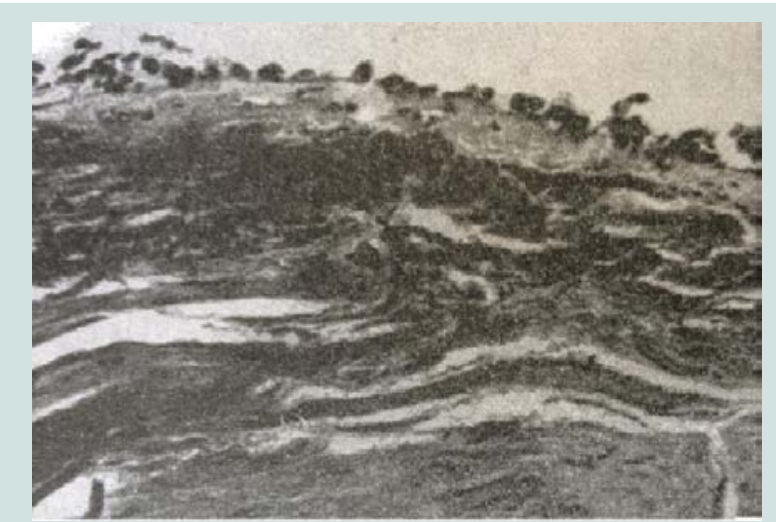

Figure 1: Biopsy from a large bronchus. Thick histological section Translation of the caption: prolonged exposure to coal dust and vibration. Atrophy of bronchial epithelium, sclerosis and hyperelasosis of the lamina propria mucosae [46]. Van Gieson stain, X 250.

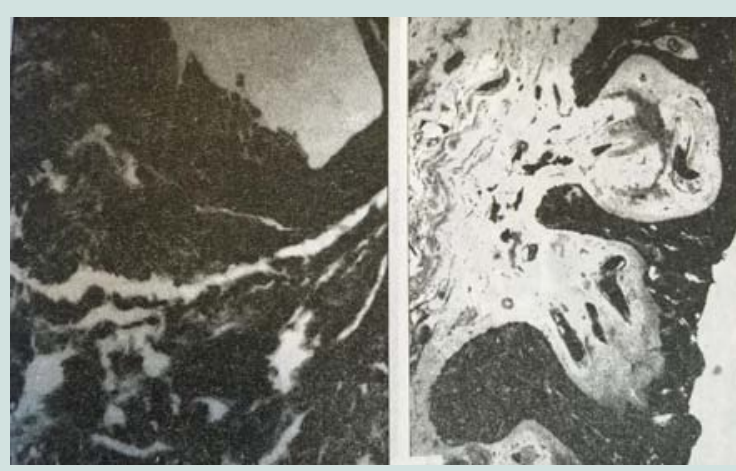

Figure 2: Light-optical examination of biopsies from large bronchi of patients with lung cancer: left - pronounced atrophy of bronchial epithelium (van Gieson stain $X 160$ ); right - squamous transformation of bronchial epithelium (semi-thin section, Azure II stain, $X$ 1000) [77].

additional damage. Not only flexible but also rigid bronchoscopes have been used e.g. in chronic bronchitis or asthma also in children $[47,48]$. For acute pneumonia in children, Bs was recommended to determine the type of inflammation in the bronchi (catarrhal, purulent); in chronic pneumonia Bs was held necessary for the same purpose and also to rule out $\mathrm{Tb}$ and congenital conditions [10]. In pediatric chronic pneumonia, Bs was recommended by the Ministry of Health for the diagnosis and therapy as "one of the main methods" [49].

Furthermore, broncho- and gastrodoudenoscopy were used as a second step of the screening e.g. in the "chronic non-specific pulmonary diseases" (including asthma and chronic bronchitis) reportedly found in $4.08 \%$ of children residing in industrially contaminated areas of Moscow and the suburbs [50]. Bs was used as a screening method in agricultural workers contacting with dust: both in healthy ones and in those with allergic rhinitis or chronic bronchitis [51]; in bronchitis patients professionally contacting with proteolytic enzymes [52]; generally in bronchitis, acute and chronic pneumonia including children [53-57]; in young (mean age 19.5 years) patients diagnosed with community-acquired pneumonia (1478 bronchoscopies in 977 patients) [58].
Bs was applied in all forms of $\mathrm{Tb}$ in many institutions and research cohorts [59-65] also when Tb was suspected [66,67]; it was recommended for young patients with "hyperergic" (high degree of hypersensitivity) tuberculin tests [68] or within the diagnostic algorithm for cases of suspected $\mathrm{Tb}$ with the sputum negative for Mycobacteria [69]. Primary Tb was regarded as an indication for Bs in children [10], although it is reportedly no more sensitive for the culture of Mycobacteria than gastric aspiration [6,7]. In destructive $\mathrm{Tb}$, therapeutic Bs (1-2 weekly during 2-4 months) was recommended by the Ministry of Health [70] and applied, while the principle of informed consent was insufficiently known and observed. Bs was used as a screening method for $\mathrm{Tb}$ in patients with general malaise, both positive and negative tuberculin tests [71]. Other researchers used Bs as a second step screening method for Tb in children [72]. Endoscopic monitoring of the therapy results has been applied in pulmonary $\mathrm{Tb}$ with non-specific bronchial lesions, also recently [62,73].

\section{Research Quality, Indications, and Informed Consent}

As mentioned above, bronchial biopsy specimens were used for research, whereas some histological illustrations were suboptimal quality (Figures 1-3), descriptions being stereotype, morphometric and other quantitative indices changing uniformly $[46,74]$ e.g. inflammatory indices (serum immunoglobulins, T- and B-lymphocytes, markers of phagocytosis) influenced both by the medical and surgical asthma treatment in the same direction [75]. Trimming of data was known to occur and proven in some studies; more details and references are in [76]. In some bronchial biopsy studies, scanning electron microscopy was the only morphological method applied [54]. Some histological descriptions were doubtful e.g. "atrophic processes" in bronchi of asthmatic children increasing with time: atrophy or "subatrophy" reportedly found in $79.5 \%$ of asthmatic children older than 12 years [47]. Biopsies were taken for research from large bronchi of patients with known lung cancer, whereas quality of histological and ultrastructural images was low (Figures 2 and 3) [77], which means additional discomfort for the cancer patients with no impact on the therapy. Another example: lavage fluid collected by Bs from patients with lung cancer and from those with $\mathrm{Tb}$ (including focal forms, tuberculoma etc.) was examined by infrared spectroscopy with no known repercussions for theory and practice [78].
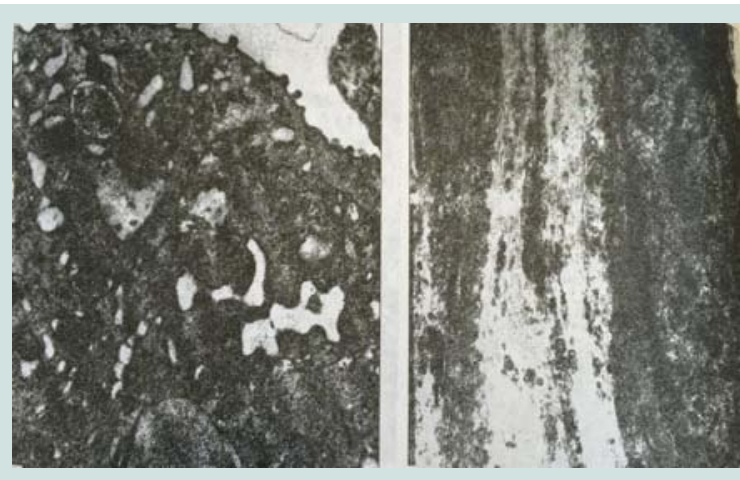

Figure 3: Bronchoscopic biopsy from a large bronchus. Translation of the caption [75]: left - destruction of cilia and formation of microvilli on the apical surface, alteration of cytoplasmatic organelles; right - endothelium-like bronchial epithelial cell, X 8000 . 
In the pediatric clinic of the Moscow Medical Academy (a leading institution where textbooks have been prepared [10]), endoscopic methods started to be broadly applied for the diagnostic, therapeutic and research purposes since the 1960s by Eva Klimanskaia and co-workers [11,12,14,39,50,79-86]. Bs was used in children with pneumonia, bronchitis and asthma [80-82], while complications were noticed [80] and "extreme carefulness" [11] recommended. Besides, gastrodoudenoscopy with biopsy used for research was applied in children with rheumatoid arthritis, dermatomyositis, scleroderma, systemic lupus erythematosus, respiratory and hepatobiliary diseases [50,83-88]. Gastroscopy was used for the screening of children born to mothers with bronchial asthma [89]. Ioffe and co-workers repeatedly applied gastrodoudenoscopy in patients with end stage kidney disease [23]. Finally, a series of studies with the overuse of cystoscopy with biopsy in connection with the overdiagnosis of malignant and premalignant urinary bladder lesions [90] has been commented previously [91].

As mentioned above, the principle of informed consent was not sufficiently known and observed [92], being mentioned only in some recent Bs studies [93-95]. Paternalistic and authoritative attitude to patients often prevailed. For example, coercive methods and compulsory treatments were applied to alcoholics: lengthy intravenous infusions (commented in [96]), sorbent hemoperfusion, endolymphatic and endobronchial delivery of antituberculosis drugs etc. [97-100]. There has been a stereotype: post-graduate students and doctoral candidates came to Moscow and other centers from different parts of the country, some of them prepared to pay for literature reviews, preparation of specimens, etc. Some researchers planning emigration completed their dissertations under the time pressure. Among others, invasive methods were applied without sufficient clinical indications sometimes in conditions of suboptimal procedural quality assurance; overviewed in [1-3]. Admittedly, as far as it can be perceived from the literature, endoscopy is less frequently used for research today. However, Bs as a screening method has been applied in the settings of military medicine [54,58]; more examples were discussed in [1]. In the recent study [93], Bs was performed in children 5-15 years of age with moderate to severe asthma, while informed consent was obtained from the children's parents.

Some bronchoscopic methods applied for diagnostics and therapy have been patented; several examples follow. Therapy monitoring of chronic catarrhal bronchitis by means of repeated examinations of bronchial washings obtained by Bs performed every other day during the whole period of treatment [101]; laser therapy via bronchoscope of "atrophic bronchitis deformans" [102-104]; bronchitis diagnostics in children and adults [105-107], treatment of pulmonary Tb by endobronchial instillations of surfactant preparations produced from bovine lung or human amniotic fluid every other day during 3-8 weeks [108]; discussed in [109].

\section{Conclusion}

The purpose of this letter was to overview some endoscopic methods, applied with questionable indications, and to remind that the risk-to-benefit ratio should be kept as low as possible. Invasive procedures including endoscopy and biopsy used for research without sufficient clinical indications fall under the jurisdiction of the Declaration of Helsinki [110]. In any case, such research presupposes integrity and informed consent. When a child is able to give assent to decisions about participation in the research, the investigator must obtain it in addition to the consent by parents or legally authorized representatives [111]. Adolescents are in a sense between children, who are to be treated according to their best interests represented by parents or legally authorized persons, and independent adults, who are to be treated according to their wishes [112]. Consent of human subjects for participation in research requires that they fully understand their role and risks, and can withdraw at any time without being disadvantaged. Children require additional protection $[113,114]$. In the author's opinion, endoscopy for research, Bs in particular, should not exist as such; it must always be performed according to clinical indications. Research can be performed on biopsy specimens obtained for diagnostic purposes (discussed in [115]). However, if suboptimal for the diagnosis methods, consuming the tissue, are applied, enough tissue must remain for the diagnostics. Note that tissue in a paraffin block may become necessary for future diagnostic examinations. In any case, the research involving humans should yield fruitful results for the good of society, being unprocurable by other methods [116]. Furthermore, medical research involving human subjects must be conducted only by experts with appropriate ethics, scientific education and training [110]. Finally, significance of the procedural quality assurance in endoscopy should be stressed. Scheduled procedures should not be performed under the time pressure. The training methods not involving patients e.g. using anatomic models and video technologies must be applied as extensively as possible [6]. Objective selection of capable trainees, prepared to dedicate most of their time for their profession, is of great importance. Nepotism $[42,43,80]$, potentially interfering with objective selection of candidates, should be discouraged. Lack of experience and skills reduces diagnostic and therapeutic yield of endoscopy while increasing risks [117]. In conclusion, practical recommendations must be based on reliable and reproducible research. Only such research should be included into reviews and meta-analyses.

\section{References}

1. Jargin SV (2016) Surgical procedures with questionable indications: a letter from Russia. J Surgery 4: 1-6.

2. Jargin SV (2014) Renal biopsy for research: an overview of Russian experience. J Interdiscipl Histopathol 2: 88-95.

3. Jargin SV (2013) Surfactant therapy of pulmonary conditions excluding those with primary surfactant deficiency and bronchoscopy as delivery method: an overview of Russian patents and publications. Recent Pat Drug Deliv Formul 7: 134-137.

4. Jargin SV (2016) On the endoscopic methods used in pediatrics with questionable indications. Ann Med Surg 10: 8-10.

5. Kavuru MS, Dweik RA, Thomassen MJ (1999) Role of bronchoscopy in asthma research. Clin Chest Med 20: 153-189.

6. Feinsilver SH, Fein A (1995) Textbook of bronchoscopy. Williams \& Wilkins, Baltimore, USA.

7. McIntosh N, Helms PJ, Smyth RL (2004) Forfar \& Arneil's textbook of pediatrics: 6th edition. J R Soc Med 97: 96.

8. Barnes PJ, Rodger IW, Thomson NC (1998) Asthma: basic mechanisms and clinical management. Thorax 53: 1096.

9. Nolte D (1984) Asthma: Das Krankheitsbild, der Asthmapatient, die Therapie. Urban \& Schwarzenberg, München. 
10. Isaeva LA (1994) Pediatrics. Meditsina, Moscow.

11. Klimanskaia EV (1972) Basics of pediatric bronchoscopy. Meditsina, Moscow.

12. Klimanskaia EV (1999) Bronchoscopy in childhood bronchial asthma. Detskil Doctor 27-29.

13. Khriachkov VV, Fedosov luN, Davydov Al, Shumilov VG, Fed'ko RV (2014) Endoscopy: basic course of lectures. Geotar-Media, Moscow.

14. Lukomskii GI, Klimanskaia EV (1976) Bronchoscopy. In: Large Medical Encyclopedia. Soviet Encyclopedia, Moscow, vol. 3, pp. 443-446.

15. Chernekhovskaia NE, Andreev VG, Povaliaev AV (2008) Therapeutic bronchoscopy in the complex therapy of respiratory organs. Medpressinform, Moscow.

16. Permanov KP, Bagdasarov VB, Abramov AS, Khodzhi-Muradov GM Babadzhanova EA (1988) Bronchial asthma in children. Zdravookhranenie Turkmenistana 40-43.

17. Shpak OI (1985) Diagnostic bronchoscopy and biopsy of central and peripheral bronchi in patients with chronic bronchitis. Dissertation, Research Institute of Tuberculosis, Kiev.

18. Vinogradova TI, Gracheva RP (1986) Principles and methods of differential diagnostics of respiratory tuberculosis in children. Institute of Advanced Medical Training, Moscow.

19. Chukhrienko DP (1966) Bronchoscopy in the diagnostics and treatment of pulmonary diseases. Zdorov'ia, Kiev.

20. Altyparmakov A (1961) Bronchoscopy and bronchography. Medgiz, Moscow

21. Ioffe LTs (1976) Non-tuberculosis pulmonary diseases, their diagnosis and treatment. Znanie, Alma-Ata.

22. Ioffe LTs, Verbolovich VP, Demchenko LK, Zharkova TG (1984) Complex bronchological and biochemical characteristics of the bronchial changes in lung disease patients. Ter Arkh 56: 82-84.

23. Aliev MA, loffe LTs, Kashkin KA, Goncharov Al, Ismagilov RZ (1987) Role of endoscopy in the diagnosis and treatment of lesions of the digestive system in patients with uremia. Klin Khir 61-63.

24. Uglov FG, Sokolov SN, Gerasin VA, Moiseev NV, Molodtsova VP (1971) Features of bronchial tree sanation in patients with bronchial asthma. Klin Med (Mosk) 49: 64-70.

25. Uglov FG (1976) Pathogenesis, clinic and therapy of chronic pneumonia Meditsina, Moscow.

26. Uglov FG (1971) Bronchological diagnostic methods of pulmonary diseases All-Union Research Institute of Pulmonology, Leningrad.

27. Roll-Hansen N (2005) The Lysenko effect: undermining the autonomy of science. Endeavour 29: 143-147.

28. Balalykin DA (2004) Introduction of pathogenic principles of surgical treatment of ulcer disease in Russian surgery. Khirurgiia (Mosk) 73-78.

29. Karimov DS, Zarzar AS, Islamkhodzhaev PS, Sabirov DS, Atadzhanov D (1972) Anesthesia in bronchoscopy of patients with bronchial asthma. Vestn Khir Im I I Grek 109: 97-99.

30. Ovcharenko SI, Romanova LK, Filippov VV, Mladkovskaia TB (1992) The clinico-cytological parallels in exacerbated bronchial asthma. Ter Arkh 64 54-58.

31. Pugachev VS, Onishko NA, Nikolenko VA, Klimenko VI (1983) Anesthesiological management in therapeutic-diagnostic bronchoscopy of bronchial asthma. Vrach Delo 50-54.

32. Fedoseev GB, Khlopotova GP (1988) Bronchial asthma. Meditsina Leningrad.

33. Skopina El (1980) Bronchoscopy in diagnostics and treatment of different clinical varieties of infectious-allergic bronchial asthma. Dissertation, Saratov Medical Institute.
34. Gerasin VA, Sobchenko SA, Zhuravlev AV (1971) Bronchoscopic characteristics of the bronchial tree in patients with bronchial asthma. Ter Arkh 43: 90-93.

35. Sobchenko SA (1977) Diagnostic bronchoscopy and bronchial biopsy in patients with bronchial asthma. Dissertation, Research Institute of Pulmonology, Leningrad.

36. Kliachkin LM, Skopina El (1982) Bronchoscopy in the treatment of bronchial asthma of infectious allergic origin. Ter Arkh 54: 76-79.

37. Krivosheeva IM, Bogadel'nikov IV, Sleptsov VP, Ermushkina TG (1988) Cytologic research on bronchoalveolar washings in nonspecific lung diseases in children. Pediatriia 99-102.

38. Chistiakov GM, Livshits MB, Abrosimova NA (1970) Endobronchial changes in children with bronchial asthma. Vopr Okhr Materin Det 15: 43-48.

39. Klimanskaia BV, Shekhter AB, Sosiura VKh, Dvornikova OG, Novikova AV, et al. (1989) Clinico-morphological analysis of the results of endobronchial use of helium-neon laser in the treatment of chronic pneumonia in children. Grudn Khir 59-64.

40. Shesterina MV, Maliev BM (1993) Diagnostic and therapeutic bronchoscopy. Tuberkulez i ekologiia 40-44.

41. Chernekhovskaia NE (2011) Lasers in endoscopy. Medpress-Inform, Moscow.

42. Nepomniashchikh GI, Nepomniashchkikh IM (1990) The intravital pathologicoanatomical diagnosis and prognosis of chronic inflammatory processes in the lungs. Arkh Patol 52: 30-35.

43. Nepomniashchikh LM, Polosukhin VV, Nepomniashchikh GI (1989) An electron microscopic and radioautographic study of bronchoalveolar lavage in chronic inflammation of the lungs under the effects of helium-neon laser. Biull Eksp Biol Med 108: 117-121.

44. Sidorova LD, Naumova LA, Nepomniashchikh GI (1994) The clinical and structural-metabolic characteristics of atrophic forms of chronic bronchitis. Ter Arkh 66: 38-42.

45. Nepomniashchikh GI, Naumova LA, Nepomniashchikh LM (1994) The phenomenon of bronchial epithelial atrophy: an ultrastructural-metabolic analysis of the bronchial mucosa in chronic bronchitis. Biull Eksp Biol Med 118: $444-448$.

46. Nepomnyashchikh GI, Levitskii VA, Nepomnyashchikh LM, Aidagulova SV, Naumova LA, et al. (2000) Instability of bronchial epithelium in chronic pulmonary diseases. Bull Exp Biol Med 129: 396-399.

47. Bogatyrev AF (2001) Morphological features of airway mucosa in children with bronchial asthma. Allergologiia 7-11.

48. Shakhanov TE, Ivanov RL (1990) Therapeutic bronchoscopy with heliumneon laser irradiation. Zdravookhranenie Kazakhstana 31-33.

49. Ministry of Health of RSFSR (1976) Bronchoscopy in the complex of therapy of children with cronic pneumonia. Methodical recommendations. Chelyabinsk.

50. Klimanskaia EV, Vozzhaeva FS (2001) Combined lesions of respiratory organs and gastrointestinal tract in children from ecologically disadvantaged areas. Ross Pediatr Zh 20-23.

51. David'ian AA (1991) Bronchoscopy, cytological examination of bronchoalveolar lavage fluid and morphological characteristics of biopsy specimens of agricultural workers exposed to dust. Sov Med 62-64.

52. Kuchik AA, Dmitrukha NN, Shpak OI, latsina MF (1988) Characteristics of the immunological reactivity of patients with chronic bronchitis working in the manufacture of proteolytic enzymes. Ter Arkh 60: 45-48.

53. Lishke AA, Novikov VN (1990) Cytologic and microbiological examination of bronchial contents in chronic lung diseases in children. Vestn Khir Im I I Grek 144: 146-148.

54. Rannev IB (2003) Bronchoscopy in the treatment of patients with pneumonia. Dissertation, Academy of Advanced Medical Training, Ministry of Defense, Moscow. 
55. Fedchenko GG, Chernekhovskaia NE, Rannev IB (2002) Radiation and endoscopic diagnosis of pneumonia. Vestn Rentgenol Radiol 21-26.

56. Shpak OI, Rolik LV, Gomoliako IV (1984) Morphoendoscopy comparisons and analysis of bronchoalveolar washings in patients with chronic bronchitis. Probl Tuberk 53-57.

57. Chernushenko EF, Belianovskaia TI, Rolik LV, Kuznetsova LV, Shpak Ol (1984) Determination of alveolar macrophage function in nonspecific lung diseases by the simultaneous estimation of phagocytosis and acid phosphatase activity. Zh Mikrobiol Epidemiol Immunobiol 84-86.

58. Kazantsev VA (2004) The use of bronchological sanation for treatment of community-acquired pneumonia. In: Abstract book, 3rd Congress of European Region. International Union against Tuberculosis and Lung diseases (IUATLD), 14th National Congress of Lung diseases, Moscow, pp. 361.

59. Kvasnitskii BI, Voloshchuk EO (1984) Frequency and nature of bronchial changes based on data from a provincial tuberculosis dispensary. Vrach Delo 56-58.

60. Lebedev KM, Filippov VP, Vasil'ev Vlu, Bolotov PA (1989) Use of carbon dioxide laser in the treatment of tuberculosis of the bronchi and trachea in children and adolescents. Probl Tuberk 30-33.

61. Bubochkin BP, Sobolev GS, Radchenko TN (1989) The endoscopic bronchial picture of patients with pulmonary tuberculosis of various age groups. Probl Tuberk 19-22.

62. Berzner AN, German AK, Kovalenbko BA, Kostrub LA, Li BP (1988) Treatment effectiveness in intrathoracic tuberculosis in children and adolescents and the characteristics of the residual posttuberculosis changes. Probl Tuberk 32-34.

63. Belen'kii MS, Balon NB (1977) Diagnostic and therapeutic bronchoscopy under conditions of a district antituberculosis dispensary. Probl Tuberk 4548.

64. Spitsyna TA, Gerasin VA, Molodtsova VP, Odintsov Al (1984) Bronchial changes in children with primary tuberculosis. Probl Tuberk 26-30.

65. Chernushenko EF, Shatrov VA, Belianovskaia TI, Kuznetsova LV, Shpak OI (1986) The function of phagocytosing cells in pulmonary tuberculosis patients. Probl Tuberk 59-63.

66. Nikolaev IS, Mishanov RF, Patsenker II (1982) Early detection of tuberculosis and nontuberculous lung diseases. Probl Tuberk 31-34.

67. Lebedeva LV, Sokolova GB, Nikolaeva NV, Konovalova RK (1974) Methods of detection and diagnosis of minor forms of tuberculosis in children and adolescents. Probl Tuberk 4-7.

68. Chelidze AV, Chernousova Tla, Karpukhina NV, Khorosheva MN, Moiseenko LM (1982) Bronchial status in children, adolescents and young people with elevated tuberculin sensitivity. Probl Tuberk 27-30.

69. Palamarchuk GF, Elkin AV, Kuzmin-Krutetskii MI, Sudomoin DS, Selizarova EM, et al. (2015) Bronchological methods in the complex diagnostics of tuberculosis and sarcoidosis of respiratory organs. North-Western Medical University, Saint Petersburg.

70. Ministry of Health of RSFSR (1982) Endobronchial methods of tuberculosis treatment. Moscow.

71. Belen'ki MS (1962) Diagnosis of chronic tuberculosis intoxication on adults Dissertation, Kharkov Medical Institute.

72. Aksenova VA, Rozinova NN, Mokhnachevskaia Al, Kravchenko AF (2005) Detection of tuberculosis in children and adolescents with non-specific pulmonary pathology in public health institutions. Sechenov Moscow Medical Academy.

73. Filippov VP, Chernichenko NV (2014) Bronchoscopy in pulmonary diseases. Binom, Moscow.

74. Smakov GM, Evdokimov Al, Baskova OV (1995) Prognostication of the effect of therapeutic bronchoscopy in patients with bronchial asthma according to the state of local immunity. Klin Med (Mosk) 73: 76-77.
75. Savchenko ZI (1982) State of immunological reactivity during surgical treatment of patients with bronchial asthma. In: Babichev SI (Ed.) Some aspects of surgical treatment of bronchial asthma. MMSI, Moscow, pp. 1326.

76. Jargin SV (2011) Pathology in the former Soviet Union: scientific misconduct and related phenomena. Dermatol Pract Concept 1: 75-81.

77. Nepomniashchikh LM, Levitskii VA, Nepomniashchikh GI, Aidagulova SV Belov Ilu, et al. (2000) Pathomorphologic and endoscopic analysis of large bronchi during lung cancer. Biull Eksp Biol Med 129: 347-351.

78. Gelfond ML (1996) Diagnosis of tuberculosis by means of infrared spectroscopy of the bronchial lavage fluid. Dissertation, Research Institute of Tuberculosis, Moscow.

79. Klimanskaia EV, Sosiura VKh, Deinichenko KV (1965) Bronchoscopy in infants with acute pneumonia. Pediatriia 44: 3-4

80. Dombrovskaia IuR, Perl'man MI, Klimanskaia EV, Klimanskii VA (1967) Some problems of pediatric pulmonology. Pediatriia 46: 50-56.

81. Novikova AV, Klimanskaia EV, Shershevskaia Ala, Erdes SI, Sosiura VKh et al. (1996) The immunomorphology of the mucosa of the bronchi and gastroduodenal zone in children with combined disease of the bronchi and gastrointestinal tract. Arkh Patol 58: 12-16.

82. Klimanskaia EV, Kodolova IM, Sosiura VKh, Tiurin NA (1974) Clinicomorphological comparisons in bronchial asthma and chronic nonspecific pneumonia in children. Pediatriia 53: 12-16.

83. Musaev SN, Novikova AV, Klimanskaia EV, Shershevskaia Ala (1991) Clinico-endoscopic and morphometric characteristics of gastric and duodenal mucosa in children with dermatomyositis. Revmatologiia (Mosk) 21-25.

84. Chumakov AM, Klimanskaia EV, Daurova NV, Deliagin VM (1986) Morphological and endoscopic characteristics of chronic gastroduodenitis in children with lesions of the hepatobiliary system and pancreas. Arkh Patol 48: $57-64$

85. Musaev SN, Novikova AV, Shershevskaia Ala, Klimanskaia EV, Aksenova IV (1991) The morphometric and immunohistochemical characteristics of the gastric and duodenal mucosa in systemic lupus erythematosus. Biull Eksp Biol Med 111: 203-206.

86. Klimanskaia EV, Daurova NV, Chumakov AM, Uvarova NN (1986) Lesions of the upper segments of the gastrointestinal tract in children with scleroderma. Revmatologiia (Mosk) 26-29.

87. Shakhbazian IE, Garkusha MB, Sklianskaia OA, Ali Nlu, Daurova NV, et al. (1991) Campylobacter pylori gastroduodenitis in children with juvenile rheumatoid arthritis. Revmatologiia (Mosk) 23-28.

88. Tsoi EA, Balabolkin II, Geppe NA, Erdes SI (2004) The symptoms of gastroesophageal disease from children with asthma. In: Abstract book. 3rd Congress of European Region, International Union against Tuberculosis and Lung diseases (IUATLD), 14th National Congress of Lung diseases, Moscow, pp. 213.

89. Geppe NA, Kuzmenko LE, Sazhina NA, Farobina EG (2004) Clinical and laboratory examination of children born to mothers with bronchial asthma. In: Abstract book. 3rd Congress of European Region, International Union against Tuberculosis and Lung diseases (IUATLD), 14th National Congress of Lung diseases, Moscow, pp. 184.

90. Romanenko A, Kakehashi A, Morimura K, Wanibuchi H, Wei M, et al. (2009) Urinary bladder carcinogenesis induced by chronic exposure to persistent low-dose ionizing radiation after Chernobyl accident. Carcinogenesis 30 : 1821-1831.

91. Jargin SV (2014) Chernobyl-related bladder lesions: new interpretation required. J Interdiscipl Histopathol 2: 96-97.

92. Lichterman BL (2005) Basic problems of medical ethics in Russia in a historical context. J Int Bioethique 16: 43-53.

93. Fedorov IA, Wilson SJ, Davies DE, Holgate ST (2005) Epithelial stress and structural remodelling in childhood asthma. Thorax 60: 389-394. 
94. Ogorodova LM, Selivanova PA, Gereng EA, Bogomiakov VS, Volkova LI, et al. (2008) Pathomorphological characteristics of unstable bronchial asthma (brittle phenotype). Ter Arkh 80: 39-43.

95. Budkova AA, Volkova LI, Budkov SR, Bogomiagkov VS (2003) Clinicomorphological assessment of budesonide efficiency in patients with bronchial asthma. Ter Arkh 75: 48-51.

96. Jargin SV (2016) Alcohol and alcoholism in Russia: insider's observations and review of literature. J Addiction Prevention 4: 1-6.

97. Utkin VV, Mikheeva LP, Omelianovich IL, Epshtein TV, Palei ME (1987) Treatment of patients with pulmonary tuberculosis in a tuberculosis hospital with open regime. In: Treatment of respiratory tuberculosis. Collection of works, Research Institute of Tuberculosis, Moscow, vol. 46: 144-148.

98. Pilipchuk NS, Melnik VP, Sribnyi SM, Petrova IE, Kulakov SV, et al. (1987) Rational chemotherapy of pulmonary tuberculosis in patient with chronic alcoholism. In: Treatment of respiratory tuberculosis, Collection of works, Research Institute of Tuberculosis, Moscow, vol. 46: 148-151.

99. Ministry of Health of Ukrainian SSR (1987) Special features of detection diagnostics, clinical course, treatment and prevention of tuberculosis in patients with chronic alcoholism. Methodical recommendations, Kiev.

100. Krut'ko VS, Stadnikova AV, Chesak OI, Kol'tsova IA, Sokol TV, et al. (1990) The efficacy of the combined therapy of chronic alcoholics with newly detected destructive pulmonary tuberculosis. Vrach Delo 70-71.

101. Zboromirskii VV, Pilipchuk VN, Protsiuk RG (1997) Evaluation method of treatment efficiency of chronic catarrhal bronchitis. Patent of Russian Federation 2079140

102. Chernekhovskaia NE, Povaliaev AV, Normanskii VE (1994) Treatment method of atrophic bronchitis deformans. Patent of Russian Federation 2014104.

103. Chernekhovskaia NE, Povaliaev VA (1995) Results of endobronchial lase irradiation treatment of patients with atrophic deforming bronchitis. Klin Med (Mosk) 73: 29-32

104. Shiriaeva EN (2007) Diagnostic and therapeutic bronchoscopy in patients with bronchitis deformans complicated by bleeding. Dissertation, Botkin Clinical Hospital, Moscow.
105. Bogadelnikov IV, Kubyshkin AV, Gavalova NG (1995) Method to establish indications for the use of preparations of proteinases or their inhibitors for the treatment of non-specific bronchitides in children. Patent of Russian Federation 2032910.

106. Novikov VN, Verkholantsev luA (1997) Diagnostic method of endobronchitis. Patent of Russian Federation 2073866.

107. Gruzintseva OE, Novikov VN (1990) Value of cytological examination of bronchial and nasal contents in the diagnosis and evaluation of the effectiveness of antibacterial therapy of recurrent bronchitis in children. Pediatriia 109-110.

108. Erokhin VV, Lovacheva OV, Lepekha LN, Rozenberg OA, Seiliev AA, et al. (2002) Treatment method of pulmonary tuberculosis. Patent of Russian Federation 2195313.

109. Jargin SV (2012) Surfactant preparations for tuberculosis and other diseases beyond infancy: a letter from Russia. Tuberculosis (Edinb) 92 280-282.

110. (2013) WMA Declaration of Helsinki - Ethical principles for medical research involving human subjects. Last amended.

111. Neill SJ (2005) Research with children: a critical review of the guidelines. $J$ Child Health Care 9: 46-58.

112. Dickens BM, Cook RJ (2005) Adolescents and consent to treatment. Int J Gynaecol Obstet 89: 179-184.

113. Bernat JL (2001) Informed consent. Muscle Nerve 24: 614-621.

114. Kuther TL, Posada M (2004) Children and adolescents' capacity to provide informed consent for participation in research. Adv Psychol Res 32: 163173

115. Jargin SV (2016) On the use of human tissues in research and practice. J Interdiscipl Histopathol 4: 46-47.

116. The Nuremberg Code, 1949.

117. Moser KM (1980) Fiberoptic bronchoscopy and other diagnostic procedures. In: Isselbacher KJ, et al. (Eds), Harrison's principles of internal medicine. McGraw-Hill, New York, pp. 1200-1201. 